\title{
A Near-Infrared Ratiometric Two-Photon Probe for pH Measurement in Human Stomach Cancer Tissue
}

Vinayak Juvekar, ${ }^{\neq \mathcal{S}_{\perp}}$ Chang Su Lim, ${ }^{\neq \mathcal{S}_{\perp}}$ Dong Joon Lee, ${ }^{\perp}$ Deuk Hwa Song, ${ }^{\perp}$ Choong-Kyun Noh, ${ }^{\dagger}$ Hyuk Kang, ${ }^{\S}$ Sung Jae Shin, *† and Hwan Myung Kim*\$ ${ }^{*}$

${ }^{\S}$ Department of Chemistry and ${ }^{\perp}$ Department of Energy Systems Research, Ajou University, Suwon 16499, South Korea; Email: kimhm@ajou.ac.kr

${ }^{\dagger}$ Department of Gastroenterology, Ajou University School of Medicine, Suwon 16499, South Korea; Email: shsj9128@ajou.ac.kr

$¥$ V. J. and C. S. L. contributed equally to this work. 
Table of Contents

Figure S1. Two-photon absorption cross section ( $\delta$ ) values of HCC1 under different TP wavelength in PBS buffer at pH 4.0, 7.0 and 9.5 .

Figure S2. (a) Optimized ground state geometries of protonated HCC1 in acidic solvent and its deprotonated form in basic solvent, respectively. (b) Optimized $\mathrm{S}_{1}$ state geometries of protonated $\mathrm{HCC} \mathbf{1}$ in acidic solvent and its deprotonated form in basic solvent, respectively. (c) Simulated absorption and emission spectra of protonated and deprotonated forms of HCC1. (d) Natural transition orbitals (NTO) involved in $\mathrm{S}_{0}-\mathrm{S}_{1}$ transition and difference electron density between $\mathrm{S}_{0}$ and $\mathrm{S}_{1}$ states at each $\mathrm{S}_{0}$ minimum structure. The NTOs named LUMO are lowest unoccupied transition orbitals (LUTO) or particles, and the ones named HOMO are highest occupied transition orbitals (HOTO) or holes.

Table S1. Excitation energies at $\mathrm{S}_{0}$ and $\mathrm{S}_{1}$ minimum structures and acidic and basic forms of HCC1.

Figure S3. Fluorescence intensity ratio $\left(F_{680} / F_{618}\right)$ of HCC1 $(1 \mu \mathrm{M})$ with a variety of substances in PBS buffer $(10 \mathrm{mM}, \mathrm{pH}$ 7.4) at $37^{\circ} \mathrm{C}$

Figure S4. Fluorescence intensity of HCC1 $(1 \mu \mathrm{M})$ in various concentration of $\mathrm{MeOH}$ and Glycerol mixture. The excitation wavelength was $530 \mathrm{~nm}$.

Figure S5. Co-localization assays of HCC1 $(2 \mu \mathrm{M})$ and commercial organelle trackers (1 $\mu \mathrm{M})$ for (a) mitochondria, and (b) S8 lysosome in HeLa cells.

Figure S6. ${ }^{1} \mathrm{H}-\mathrm{NMR}$ and ${ }^{13} \mathrm{C}-\mathrm{NMR}$ spectra of HCC1 dye in Methanol- $d_{4}$

Figure S7. High resolution mass spectrometry (HRMS) data of HCC1 dye 


\section{General information.}

\section{Materials and Methods.}

All chemicals and reagents were purchased from commercial suppliers and used without further purification. All solvents were purified by a solvent purifier prior to HCC1 synthesis by standard methods. Stock solutions of the probe were prepared by dissolving in DMSO (Sigma-Aldrich, St. Louis, MO, USA). The synthesis results were characterized by ${ }^{1} \mathrm{H}-\mathrm{NMR},{ }^{13} \mathrm{C}-\mathrm{NMR}$, and ESI high-resolution mass spectrometry. ${ }^{1} \mathrm{H}-\mathrm{NMR}$ and ${ }^{13} \mathrm{C}-\mathrm{NMR}$ spectra were recorded using a Bruker $600 \mathrm{MHz}$ spectrometer using $\mathrm{CDCl}_{3}$ and $\mathrm{Methanol-}^{-}$ $\mathrm{d}_{4}$. The chemical shifts are reported in ppm, and the coupling constant is given in $\mathrm{Hz}$. The spectra of the probe in the absorption and emission spectra were recorded using a UV-vis spectrophotometer (S-3100) and a fluorescence spectrophotometer (FluoroMate FS2) with a $1 \mathrm{~cm}$ quartz cell, respectively. The fluorescence quantum yield was determined using Cresyl violet $(\Phi=0.53$ in $\mathrm{MeOH})$ as the reference. Fluorescence images were obtained with spectral confocal microscopes (Leica TCS SP8).

\section{Measurement of TP Cross Section.}

The TP cross section $(\delta)$ was determined by using a femto-second ( $\mathrm{fs}$ ) fluorescence measurement technique as described. ${ }^{1}$ HCC1 $(5.0$ $\times 10^{-6} \mathrm{M}$ ) was dissolved in universal buffer of $\mathrm{pH} 4.0,7.0$ and 9.5 and the TP-induced fluorescence intensity were measured at $820-1040 \mathrm{~nm}$ by using rhodamine $6 \mathrm{G}$ as the reference. The TP properties of which have been well characterized in the literature. The intensities of the TP-induced fluorescence spectra of the reference and sample emitted at the same excitation wavelength were determined. The TPA cross section was calculated by using the following equation: $\delta=\delta_{r}\left(S_{s} \Phi_{r} \phi_{r} c_{r}\right) /\left(S_{r} \Phi_{s} \phi_{s} c_{s}\right)$, where the subscripts $s$ and $r$ stand for the sample and reference molecules, respectively. The intensity of the signal collected by a CCD detector was denoted as S. $\Phi$ is the fluorescence quantum yield. $\phi$ is the overall fluorescence collection efficiency of the experimental apparatus. The number density of the molecules in solution was denoted as c. $\delta_{r}$ is the TPA cross section of the reference molecule (Figure S1).

\section{Computational Method.}

Quantum mechanical calculation was done using Gaussian 09 software package. ${ }^{2}$ Ground state geometries were optimized at M062X/DEF2-SVP level of theory with SMD model for solvation in water. ${ }^{3}$ Excited state energies and geometries were calculated at TD M06-2X/DEF2-SVP level of theory with SMD solvation. From the excited state calculation results, natural transition orbitals were generated using Gaussian 09. ${ }^{4}$ It was shown that the employed computational methods successfully described the characteristics of fluorescent probes. $^{5}$

\section{Cell culture.}

HeLa human cervical carcinoma cells (KCLB, Seoul, Korea) cultured in a glass-bottomed dishes (NEST, Rahway, NJ, USA) supplemented with minimum essential medium eagle (MEM, WelGene Inc, Seoul, Korea) containing fetal bovine serum (10\% FBS, WelGene), of 10 $\mathrm{mM}$, whereas the working concentration of HCC1 $2 \mu \mathrm{M}$ (unless otherwise stated) incubated with cells, washed three times with PBS (Gibco, Gaithersburg, MD, USA), and used in obtaining fluorescence images.

\section{Cell images.}

HeLa cells were cultured for two days prior to fluorescence imaging. Cells were treated with Streptomycin (100 mg mL 1), penicillin (100 units per $\mathrm{mL}$ ), and $10 \%$ fetal bovine serum. The culture medium was replaced with a serum-free med ium and $2 \mu \mathrm{M}$ HCC1 probe was stained for $30 \mathrm{~min}$. Live cell imaging was performed using a live-cell instrument (Chaml ide IC) to control proper temperature, humidity, and $\mathrm{pH}$ for long term exposure. Ratiometric image processing and analy sis were carried out using MetaMorph software. ${ }^{6}$

\section{Co-localization experiments.}

Experiments were executed by co-staining $1 \mu \mathrm{M}$ commercial organelle tracker (LysoTracker Green DND-26 for lysosomes and MitoTracker Green FM for mitochondria) with $2 \mu \mathrm{M}$ HCC1 probe, respectively. The excitation wavelengths were 488 
$\mathrm{nm}$ (organelle trackers) and $552 \mathrm{~nm}$ (HCC1). Pearson's colocalization coefficient (A) was calculated using AutoQuant X2 s oftware. ${ }^{6}$

\section{Cell pH calibration.}

A pH calibration curve was acquired by $\left(F_{\text {orange }} / F_{\text {red }}\right)$ of ionophores-treated and HCC1-labeled HeLa cells. ${ }^{7}$ The cells were $\mathrm{t}$ reated with $2 \mu \mathrm{L}$ of $1 \mathrm{mM} \mathrm{HCC1}$ in DMSO stock solution at $37{ }^{\circ} \mathrm{C}$ and $5 \% \mathrm{CO}_{2}$ for $30 \mathrm{~min}$, and subsequently the extra cellular media was substituted by $1 \mathrm{~mL}$ of calibration buffer $(125 \mathrm{mM} \mathrm{KCl}, 20 \mathrm{mM} \mathrm{NaCl}, 0.5 \mathrm{mM} \mathrm{CaCl}, 0.5 \mathrm{mM} \mathrm{MgCl}$, $5 \mathrm{mM}$ nigericine, $5 \mathrm{mM}$ monensin, and $25 \mathrm{mM}$ buffer; sodium Acetate for 4.0; 2-(N-morpholino)ethanesulfonic acid (ME S) for $\mathrm{pH} 5.0$ and 6.0 ; N-(2-hydroxyethyl)-piperazine-N'-2-ethanesulfonic acid (HEPES) for 7.0 to 10.0). The cells were inc ubated with the calibration buffer for $15 \mathrm{~min}$ at room temperature. Upon excitation at $552 \mathrm{~nm}$ with confocal microscop e, fluorescence intensity at 560-620 nm ( $\left.F_{\text {orange }}\right)$ and 675-725 nm $\left(F_{\text {red }}\right)$ of HCC1 well changed with pH, and we obtained $\mathrm{pH}$ calibration curve the plots of $F_{\text {orange }} / F_{\text {red }}$ versus $\mathrm{pH}$ values.

\section{Two-photon Fluorescence microscopy.}

Two-photon Fluorescence microscopy images of $15 \mu \mathrm{M}$ HCC1 labeled tissues were obtained with multiphoton microscope (Leica TCS SP8 MP) with oil immersion X 40 objectives, numerical aperture $(N A)=1.30$. Live tissues were washed with serum free media and incubated with $\mathbf{H C C 1}$ for $30 \mathrm{~min}$. The two-photon Fluorescence microscopy images were obtaine d with a DMI6000B Microscope (Leica) by exciting the probes with a mode-locked titanium-sapphire laser source (Mai T ai HP; Spectra Physics, $80 \mathrm{MHz}, 100 \mathrm{fs}$ ) set at wavelength $840 \mathrm{~nm}$ and input power $1.6 \mathrm{~mW}$. To obtain images at 560$620 \mathrm{~nm}\left(F_{\text {orange }}\right)$ and $675-725 \mathrm{~nm}\left(F_{\text {red }}\right)$ range internal PMTs were used to collect the signals $512 \times 512$ pixels; field of view, $290 \times 290 \mu \mathrm{m}$; at $80 \mathrm{~Hz}$ scan speed. Ratiometric image processing and analysis was carried out using MetaMorph software.

\section{Cell Viability.}

CCK-8 kit assay was performed to assess the cytotoxicity. HeLa cells were cultured in 96-well plate for $24 \mathrm{~h}$, and then each different concentration of HCC1 (0-50 $\mu \mathrm{M})$ was added. After incubation for $24 \mathrm{~h}$, the cultured medium was replaced with serum free medium containing $10 \%$ CCK-8, and further incubated for $2 \mathrm{~h}$. Absorbance was measured at $450 \mathrm{~nm}$. 

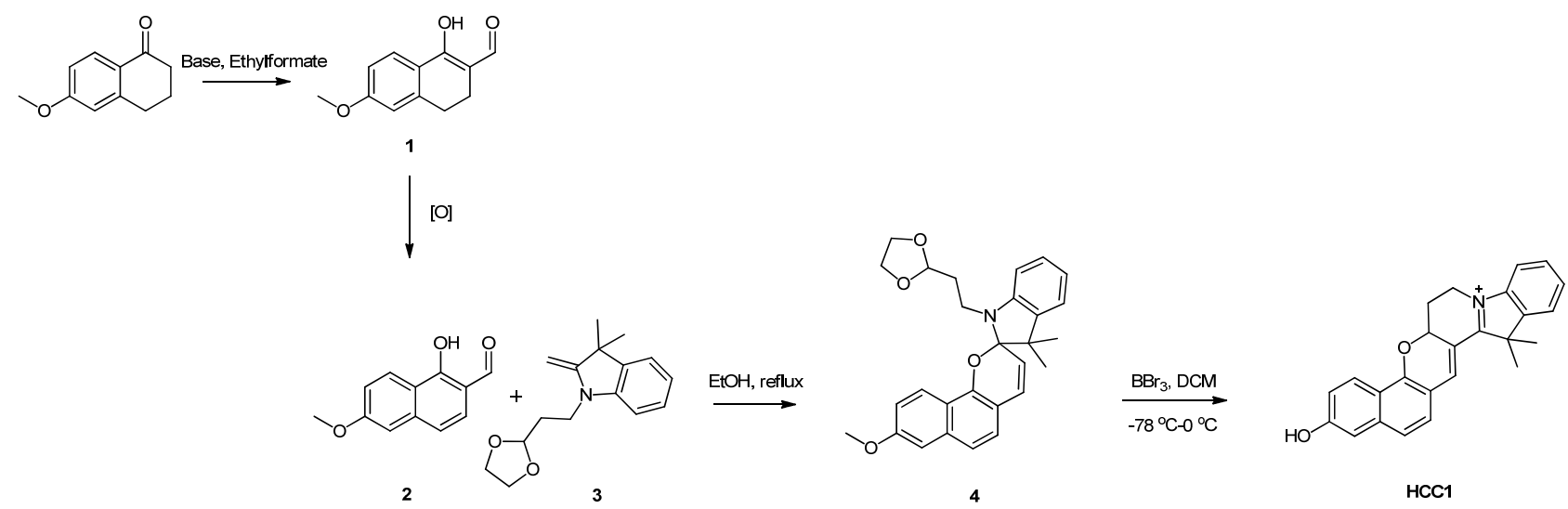

Scheme S1 Synthetic route to the HCC1.

Compound $\mathbf{2}$ synthesised by following reference elsewhere. ${ }^{8}$

Synthesis of HCC1 is explained below.

1'-(2-(1,3-dioxolan-2-yl)ethyl)-8-methoxy-3',3'-dimethylspiro[benzo[h]chromene-2,2'-indoline] (4). A mixture of 1-hydroxy-6methoxy-2-naphthaldehyde $(500 \mathrm{mg}, 2.47 \mathrm{mmol})$ and 1-(2-(1,3-dioxolan-2-yl)ethyl)-3,3-dimethyl-2-methyleneindoline (637 mg, 2.60 $\mathrm{mmol})$ in EtOH $(10 \mathrm{~mL})$ refluxed $\left(80^{\circ} \mathrm{C}\right) 48 \mathrm{~h}$. Reaction mass brought to room temperature, and cold EtOH (10 $\left.\mathrm{mL}\right)$ added to reaction mass. The reaction mass evaporated to dryness and carried out flash column chromatography with gradient from (Hexane/E.A=85:15) to (Hexane/E.A=50:50) over $30 \mathrm{~min}$ to obtain 4 (740 mg) as a dark violet solid. Yield: $67 \%$; $1 \mathrm{H}-\mathrm{NMR}\left(600 \mathrm{MHz}, \mathrm{CDCl}_{3}\right) \delta 7.81(\mathrm{~d}, \mathrm{~J}=$ $9.0 \mathrm{~Hz}, 1 \mathrm{H}), 7.20(\mathrm{q}, \mathrm{J}=7.6 \mathrm{~Hz}, 2 \mathrm{H}), 7.11(\mathrm{~d}, \mathrm{~J}=7.6 \mathrm{~Hz}, 1 \mathrm{H}), 7.01(\mathrm{~d}, \mathrm{~J}=2.1 \mathrm{~Hz}, 1 \mathrm{H}), 6.95(\mathrm{dd}, \mathrm{J}=9.3,2.4 \mathrm{~Hz}, 1 \mathrm{H}), 6.92(q, J=4.8 \mathrm{~Hz}$, $2 \mathrm{H}), 6.87(\mathrm{t}, \mathrm{J}=7.6 \mathrm{~Hz}, 1 \mathrm{H}), 6.68(\mathrm{~d}, \mathrm{~J}=8.3 \mathrm{~Hz}, 1 \mathrm{H}), 5.71-5.56(1 \mathrm{H}), 4.87(\mathrm{t}, \mathrm{J}=4.5 \mathrm{~Hz}, 1 \mathrm{H}), 3.87-3.89(\mathrm{~m}, 5 \mathrm{H}), 3.72-3.76(\mathrm{~m}, 2 \mathrm{H}), 3.50-$ $3.55(\mathrm{~m}, 1 \mathrm{H}), 3.32-3.37(\mathrm{~m}, 1 \mathrm{H}), 2.02-2.07(\mathrm{~m}, 1 \mathrm{H}), 1.92-1.98(\mathrm{~m}, 1 \mathrm{H}), 1.32(\mathrm{~s}, 3 \mathrm{H}), 1.20(\mathrm{~s}, 3 \mathrm{H})$.

4-hydroxy-15,15-dimethyl-7a,8,9,15-tetrahydrobenzo[7',8']chromeno[3',2':3,4]pyrido[1,2-a]indol-10-ium (HCC1). A mixture of 4 (250 mg, $0.56 \mathrm{mmol})$ in $\mathrm{CH}_{2} \mathrm{Cl}_{2}(25 \mathrm{~mL})$ added $\mathrm{BBr}_{3}\left(1.41 \mathrm{~g}, 5.64 \mathrm{mmol}, 1 \mathrm{M}\right.$ solution in $\left.\mathrm{CH}_{2} \mathrm{Cl}_{2}\right)$ dropwise at $-78^{\circ} \mathrm{C}$ and continued at $78{ }^{\circ} \mathrm{C}$ for $2 \mathrm{~h}$. Slowly brought the temperature to $0{ }^{\circ} \mathrm{C}$ and continued stirring for $16 \mathrm{~h}$. The orange colour reaction mass containing excess $\mathrm{BBr}_{3}$ quenched with satd. $\mathrm{NaHCO}_{3}$ and separated organic phase. After washing aqueous phase twice with $\mathrm{CH}_{2} \mathrm{Cl}_{2}$ the organic layer evaporated to dryness and purified twice with column chromatography with gradient from $\left(\mathrm{CHCl}_{3} / \mathrm{MeOH}=9.7: 0.3\right)$ to $\left(\mathrm{CHCl}_{3} / \mathrm{MeOH}=8.5: 1.5\right)$ over $30 \mathrm{~min}$ to obtain $\mathrm{HCC1}(21 \mathrm{mg})$ as a barn red solid. Yield: $11 \%$; ${ }^{1} \mathrm{H}-\mathrm{NMR}\left(600 \mathrm{MHz}, \mathrm{Methanol}-\mathrm{d}_{4}\right) \delta(\mathrm{ppm})$ $8.34(\mathrm{~s}, 1 \mathrm{H}), 8.13(\mathrm{~d}, \mathrm{~J}=9.0 \mathrm{~Hz}, 1 \mathrm{H}), 7.70(\mathrm{dd}, \mathrm{J}=13.8,8.3 \mathrm{~Hz}, 2 \mathrm{H}), 7.56-7.61(\mathrm{~m}, 2 \mathrm{H}), 7.44(\mathrm{~d}, \mathrm{~J}=8.3 \mathrm{~Hz}, 1 \mathrm{H}), 7.30(\mathrm{~d}, \mathrm{~J}=9.0 \mathrm{~Hz}, 1 \mathrm{H})$, $7.10(\mathrm{td}, \mathrm{J}=9.8,2.5 \mathrm{~Hz}, 2 \mathrm{H}), 5.63-5.60(\mathrm{~m}, 1 \mathrm{H}), 4.76(\mathrm{q}, \mathrm{J}=6.2 \mathrm{~Hz}, 1 \mathrm{H}), 4.34(\mathrm{td}, \mathrm{J}=13.8,3.7 \mathrm{~Hz}, 1 \mathrm{H}), 3.04-3.08(\mathrm{~m}, 1 \mathrm{H}), 2.76(\mathrm{qd}, \mathrm{J}=$ 12.6, $5.5 \mathrm{~Hz}, 1 \mathrm{H}), 1.85$ (s, 3H), 1.80 (s, 3H); ${ }^{13} \mathrm{C}-\mathrm{NMR}(151 \mathrm{MHz}$, Methanol-d 4 ) $\delta$ (ppm) 176.47, 160.30, 156.61, 143.64, 143.38, 140.93, 140.64, 129.10, 129.06, 126.58, 125.42, 122.60, 121.21, 118.73, 117.60, 114.99, 113.71, 113.62, 109.88, 71.39, 51.75, 42.79, 25.66, 24.61; HRMS $\left(\mathrm{ESI}^{+}\right): \mathrm{m} / \mathrm{z}$ calcd for $\left[\mathrm{C}_{25} \mathrm{H}_{22} \mathrm{NO}_{2}\right]^{+}: 368.1645$ found for $\left[\mathrm{C}_{25} \mathrm{H}_{22} \mathrm{NO}_{2}\right]^{+}: 368.1642$. 


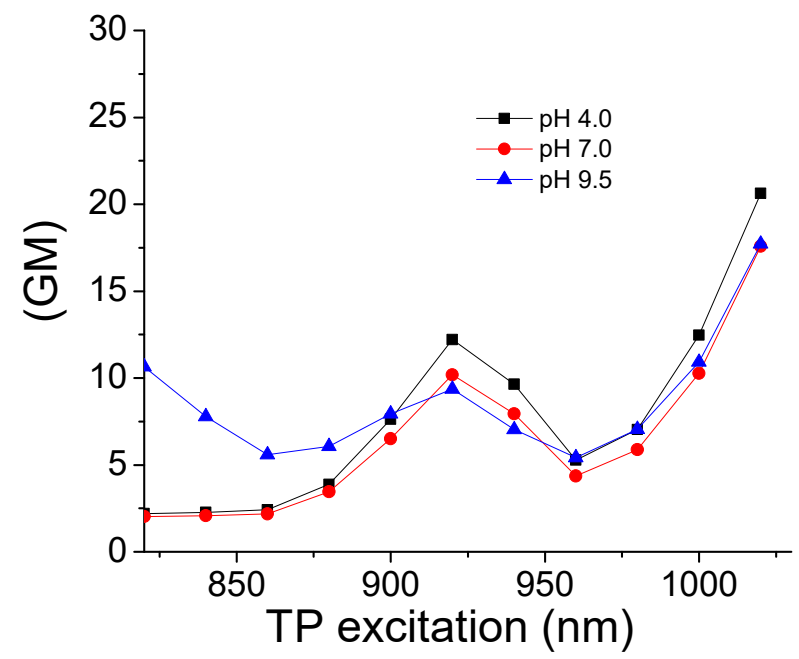

Figure S1. Two-photon absorption cross section $(\delta)$ values of HCC1 under different TP wavelength in universal buffer of pH $4.0,7.0$ and 9.5 .

(a)

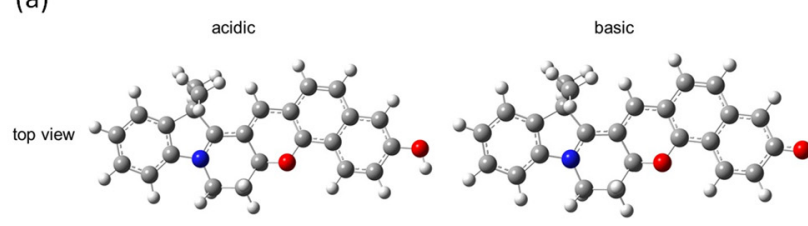

2.,

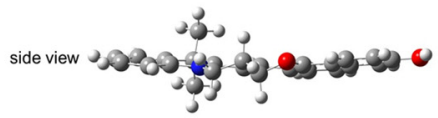

30000000

(c)

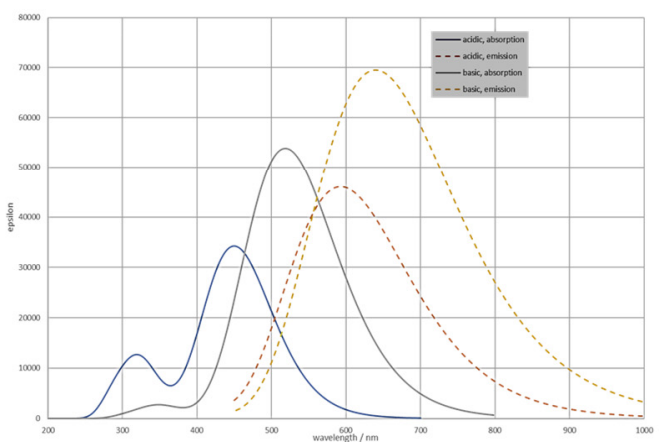

(b)

acidic
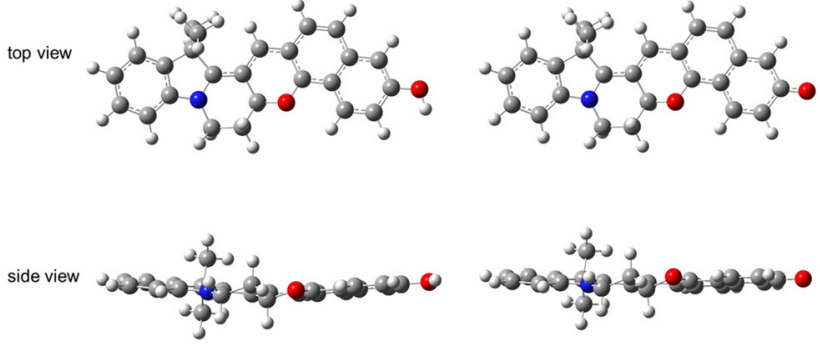

(d)
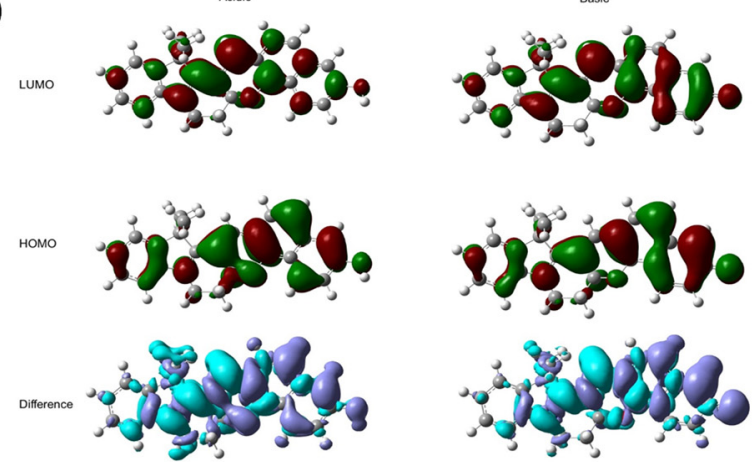

Figure S2. (a) Optimized ground state geometries of protonated HCC1 in acidic solvent and its deprotonated form in basic solvent, respectively. (b) Optimized $S_{1}$ state geometries of protonated $\mathbf{H C C} 1$ in acidic solvent and its deprotonated form in basic solvent, respectively. (c) Simulated absorption and emission spectra of protonated and deprotonated forms of HCC1. (d) Natural transition orbitals (NTO) involved in $\mathrm{S}_{0}-\mathrm{S}_{1}$ transition and difference electron density between $\mathrm{S}_{0}$ and $\mathrm{S}_{1}$ states at each $\mathrm{S}_{0}$ minimum structure. The NTOs named LUMO are lowest unoccupied transition orbitals (LUTO) or particles, and the ones named HOMO are highest occupied transition orbitals (HOTO) or holes.

Figure $\mathrm{S} 2 \mathrm{~b}$ shows the optimized geometries of protonated and deprotonated forms of $\mathbf{H C C} \mathbf{1}$ in $\mathrm{S}_{1}$ state, and it is seen that the relative angle between the benzene ring and the naphthalene ring changes when going from $S_{0}$ state to $S_{1}$ state. Therefore, low-frequency out-of-plane vibration modes are active when HCC1 is electronically excited. These out-of-plane vibration modes, when combined with the low $\mathrm{S}_{0}-\mathrm{S}_{1}$ gap of the basic form, can facilitate internal conversion via a conical intersection. ${ }^{9}$ Therefore, it is assumed that the basic form of HCC1 has lower fluorescence quantum yield due to the increased internal conversion rate. 
Table S1. Excitation energies at $\mathrm{S}_{0}$ and $\mathrm{S}_{1}$ minimum structures and acidic and basic forms of HCC1.

\begin{tabular}{|c|c|c|c|c|}
\hline & $\begin{array}{l}\text { Acidic, } S_{0} \text { minimum } \\
\text { structure }\end{array}$ & $\begin{array}{l}\text { Acidic, } \mathrm{S}_{1} \text { minimum } \\
\text { structure }\end{array}$ & $\begin{array}{l}\text { Basic, } S_{0} \text { minimum } \\
\text { structure }\end{array}$ & $\begin{array}{l}\text { Basic, } \mathrm{S}_{1} \text { minimum } \\
\text { structure }\end{array}$ \\
\hline $\mathrm{S}_{1}$ energy / eV & 2.7558 & 2.1481 & 2.3894 & 1.9508 \\
\hline$S_{2}$ energy / eV & 3.8046 & 3.3544 & 3.5154 & 3.2933 \\
\hline $\mathrm{S}_{3}$ energy / eV & 4.2561 & 3.8716 & 3.9915 & 3.5493 \\
\hline
\end{tabular}

Table S1 summarizes calculated transition energies of HCC1. Excited state energies at each $\mathrm{S}_{0}$ minimum structure are vertical electronic transition energies from each stable ground state structure, and therefore correspond to the maxima in electronic absorption bands. The energy of excited state 1 at each $S_{1}$ minimum structure correspond to the maximum in emission spectrum because fluorescence is emitted from the lowest vibrational level of the lowest excited state. The calculated excitation energies well reproduce the experimental result that HCC1 in basic aqueous solution has longer absorption and emission wavelength than in acidic solution.

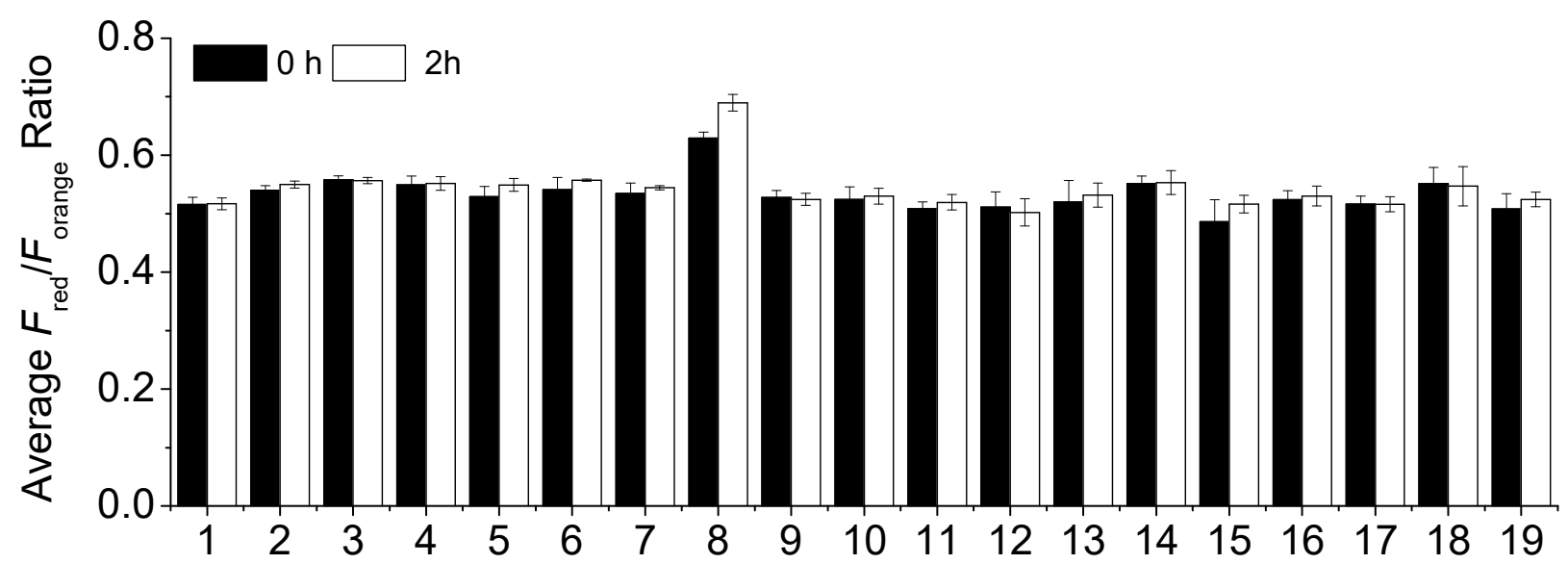

Figure S3. Fluorescence intensity ratio $\left(F_{680} / F_{618}\right)$ of $\mathrm{HCC}(1 \mu \mathrm{M})$ with a variety of substances in PBS buffer $(10 \mathrm{mM}, \mathrm{pH} 7.4)$ at $37^{\circ} \mathrm{C}$

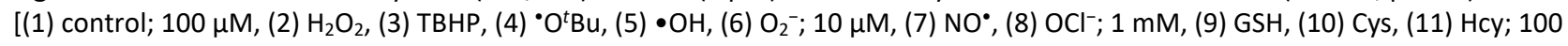
$\mu \mathrm{M},(12) \mathrm{MnCl}_{2}$, (13) $\mathrm{CuCl}_{2}$, (14) $\mathrm{ZnCl}_{2}$, (15) $\mathrm{FeCl}_{2}$, (16) $\mathrm{MgCl}_{2}$, (17) $\mathrm{CaCl}_{2}$, (18) $\mathrm{KCl}$, (19) $\mathrm{NaCl}$. The excitation wavelength was $530 \mathrm{~nm}$.

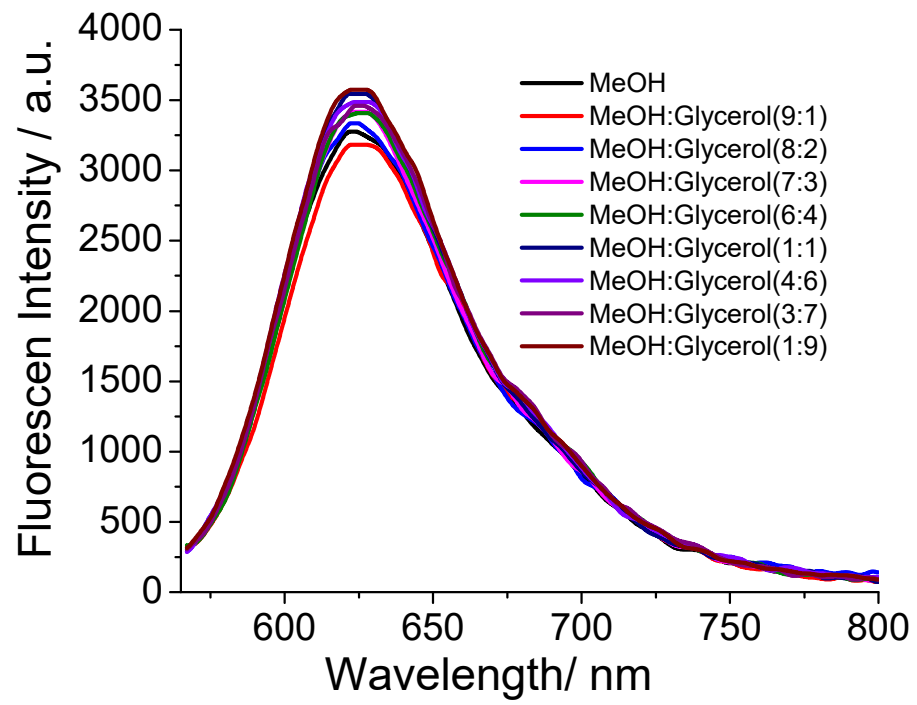

Figure S4. Fluorescence intensity of $\mathrm{HCC1}(1 \mu \mathrm{M})$ in various concentration of $\mathrm{MeOH}$ and Glycerol mixture. The excitation wavelength was $530 \mathrm{~nm}$. 
Trackers
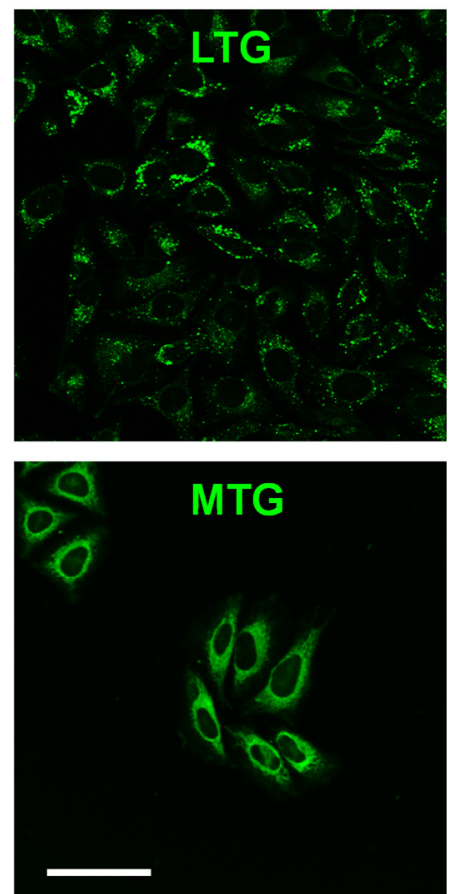

$\mathrm{HCC} 1$
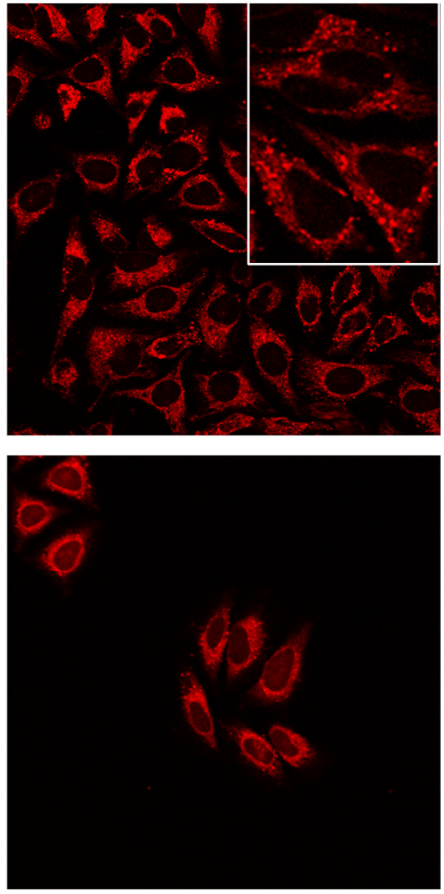

Merged
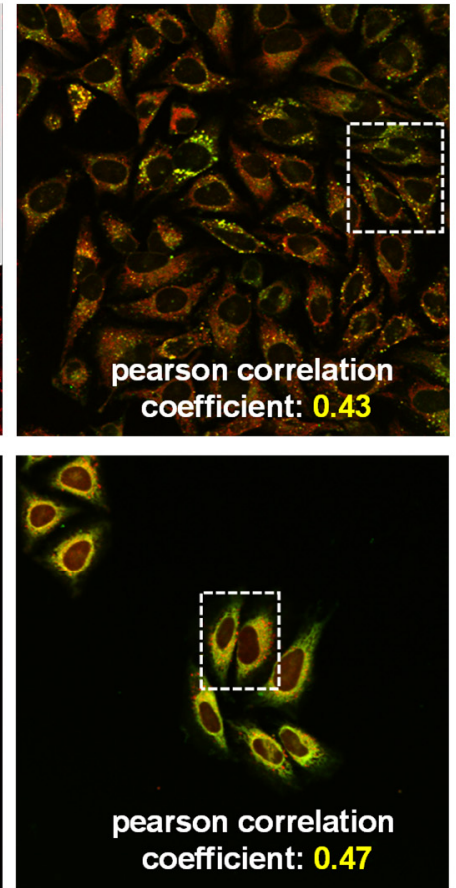

Expanded
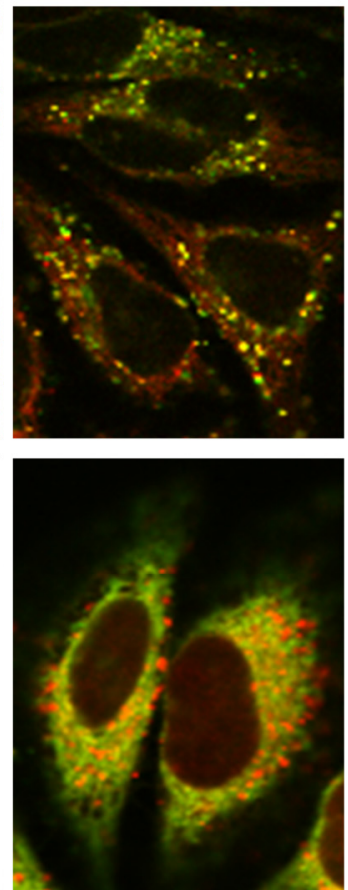

Figure S5. Co-localization assays of HCC1 (2 $\mu \mathrm{M})$ and commercial organelle trackers (1 $\mu \mathrm{M})$ for (a) mitochondria, and (b) lysosome in HeLa cells. Images were acquired using $488 \mathrm{~nm}$ (organelle trackers) and $552 \mathrm{~nm}$ (HCC1) excitation and emission windows of 495-545 nm (organelle trackers) and 600-700 nm (HCC1). Scale bar= $60 \mu \mathrm{m}$. 

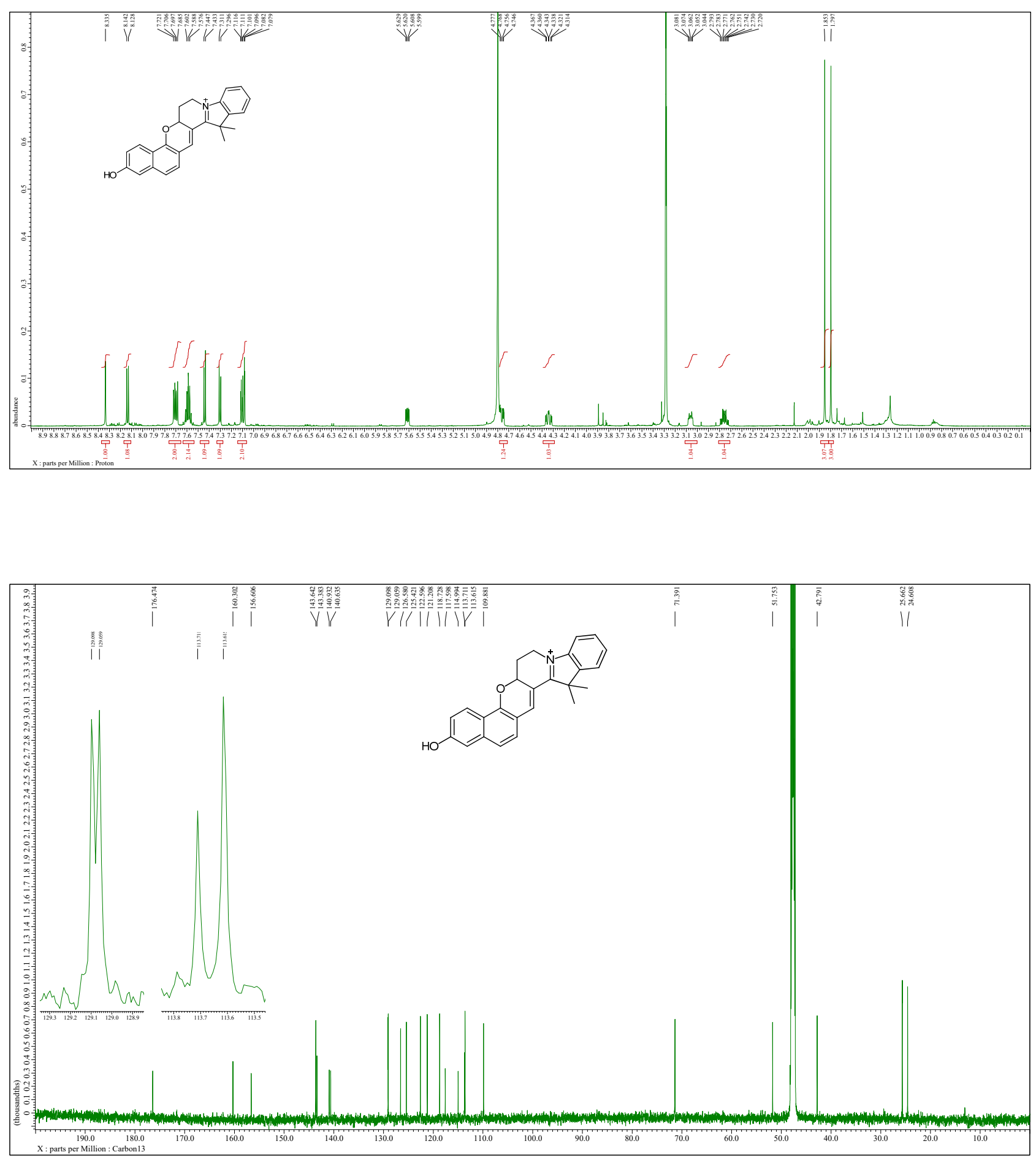

Figure S6. ${ }^{1} \mathrm{H}-\mathrm{NMR}$ and ${ }^{13} \mathrm{C}-\mathrm{NMR}$ spectra of $\mathrm{HCC1}$ dye in Methanol-d4. 
[3] MS spectrum (RT : 6.17)

OHCC2_200914121653 \#836-849 RT: 6.17-6.21 AV: 2 NL: 2.18E7

F: $F T M S+p$ ESI sid=5.00 Full ms [150.00-2000.00]

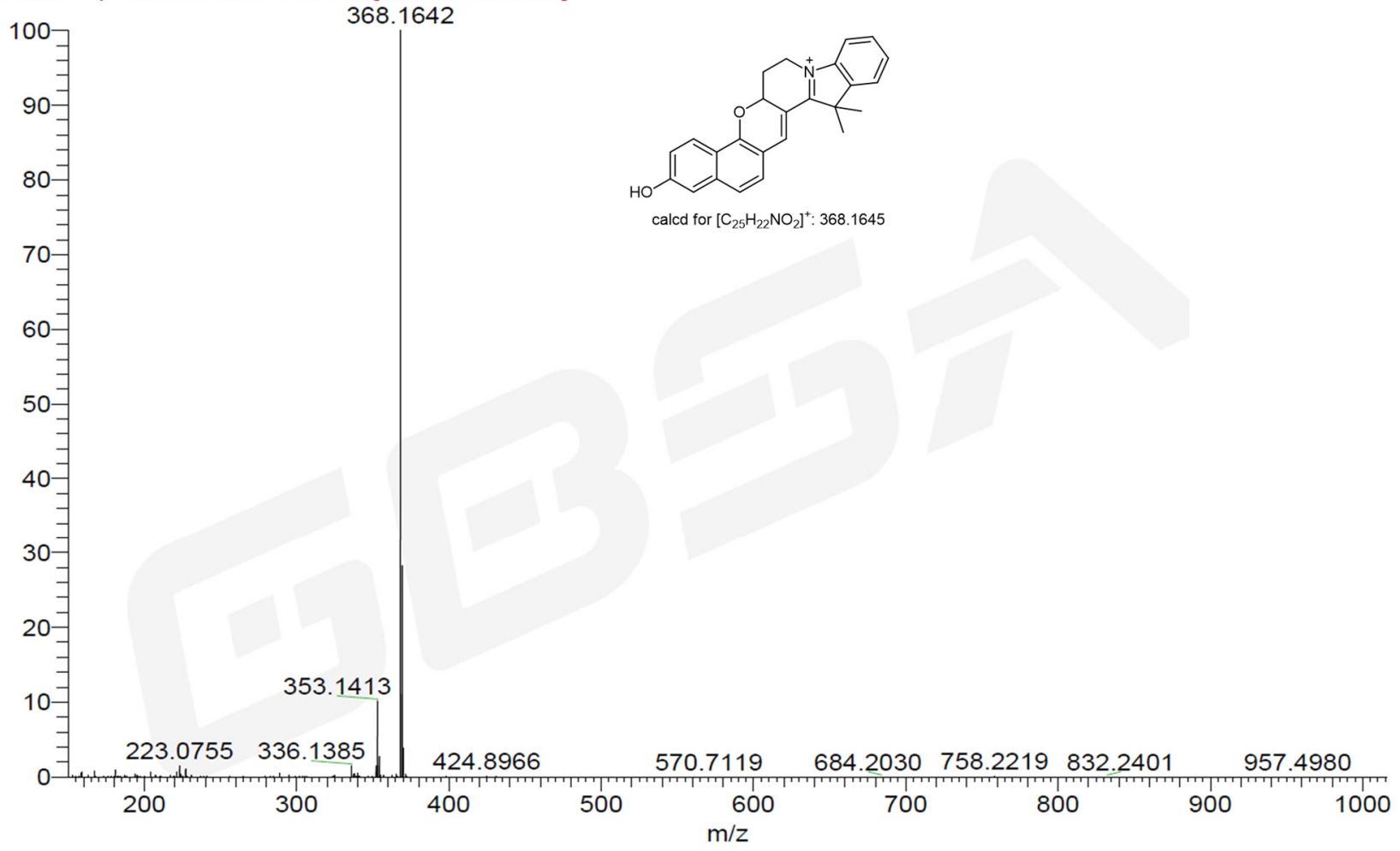

Figure S7. High resolution mass spectrometry (HRMS) data of HCC1 dye. 


\section{References}

1. Kang, D. E.; Lim, C. S.; Kim, J. Y.; Kim, E. S.; Chun, H. J.; Cho, B. R. Two-Photon Probe for $\mathrm{Cu}^{2+}$ with an Internal Reference: Quantitative Estimation of $\mathrm{Cu}^{2+}$ in Human Tissues by Two-Photon Microscopy. Anal. Chem. 2014, 86, 5353-5359.

2. Frisch, M. J.; Trucks, G. W.; Schlegel, H. B.; Scuseria, G. E.; Robb, M. A.; Cheeseman, J. R.; Scalmani, G.; Barone, V.; Petersson, G. A.; Nakatsuji, H.; Li, X.; Caricato, M.; Marenich, A. V.; Bloino, J.; Janesko, B. G.; Gomperts, R.; Mennucci, B.; Hratchian, H. P.; Ortiz, J. V.; Izmaylov, A. F.; Sonnenberg, J. L.; Williams; Ding, F.; Lipparini, F.; Egidi, F.; Goings, J.; Peng, B.; Petrone, A.; Henderson, T.; Ranasinghe, D.; Zakrzewski, V. G.; Gao, J.; Rega, N.; Zheng, G.; Liang, W.; Hada, M.; Ehara, M.; Toyota, K.; Fukuda, R.; Hasegawa, J.; Ishida, M.; Nakajima, T.; Honda, Y.; Kitao, O.; Nakai, H.; Vreven, T.; Throssell, K.; Montgomery Jr., J. A.; Peralta, J. E.; Ogliaro, F.; Bearpark, M. J.; Heyd, J. J.; Brothers, E. N.; Kudin, K. N.; Staroverov, V. N.; Keith, T. A.; Kobayashi, R.; Normand, J.; Raghavachari, K.; Rendell, A. P.; Burant, J. C.; Iyengar, S. S.; Tomasi, J.; Cossi, M.; Millam, J. M.; Klene, M.; Adamo, C.; Cammi, R.; Ochterski, J. W.; Martin, R. L.; Morokuma, K.; Farkas, O.; Foresman, J. B.; Fox, D. J. Gaussian 09, Revision C.01, Wallingford, CT, 2010.

3. Marenich, A. V.; Cramer, C. J.; Truhlar, D. G., Universal Solvation Model Based on Solute Electron Density and on a Continuum Model of the Solvent Defined by the Bulk Dielectric Constant and Atomic Surface Tensions. J. Phys. Chem. B 2009, 113, 63786396.

4. Martin, R. L., Natural transition orbitals. J. Chem. Phys. 2003, 118, 4775-4777.

5. Zhao, X.; Wang, C.; Yuan, G.; Ding, H.; Zhou, L.; Liu, X.; Lin, Q., A dual-site modulated FRET-based two-photon ratiometric fluorescent probe for tracking lysosomal pH changes in living cells, tissues and zebrafish. Sensors and Actuators B: Chemical 2019, 290, 79-86

6. Park, S. J.; Juvekar, V.; Jo, J. H.; Kim, H. M. Combining hydrophilic and hydrophobic environment sensitive dyes to detect wide range of cellular polarity. Chem. Sci. 2020, 11, 596-601.

7. Sarkar, A. R.; Heo, C. H.; Xu, L.; Lee, H. W.; Si, H. Y.; Byun, J. W.; Kim, H. M. A ratiometric two-photon probe for quantitative imaging of mitochondrial pH values. Chem. Sci. 2016, 7, 766-773.

8. Kim, H. M.; Fang, X. Z.; Yang, P. R.; Yi, J.-S.; Ko, Y. G.; Piao, M. J.; Chung, Y. D.; Park, Y. W.; Jeon, S.-J.; Cho, B. R. Design of molecular two-photon probes for in vivo imaging.2H-Benzo[h]chromene-2-one derivatives. Tetrahedron Lett. 2007, 48, 2791-2795.

9. Perun, S.; Sobolewski, A. L.; Domcke, W., Ab initio studies on the radiationless decay mechanisms of the lowest excited singlet states of $9 \mathrm{H}$-adenine. J. Am. Chem. Soc. 2005, 127, 6257-6265. 